\title{
Article \\ Exploring Different Pretreatment Methodologies for Allowing Microalgae Growth in Undiluted Piggery Wastewater
}

\author{
Alice Ferreira ${ }^{1, *}$, Daniel Figueiredo ${ }^{2}$, Rodrigo Cardeiras ${ }^{1}$, Rui Nabais ${ }^{1}$, Francisca Ferreira ${ }^{1}$, Belina Ribeiro ${ }^{1}$, \\ Cláudia M. d. S. Cordovil ${ }^{3}$ (D) F. Gabriel Acién ${ }^{4}$ (D) and Luisa Gouveia ${ }^{1,2}$ (iD)
}

1 LNEG, National Laboratory of Energy and Geology I.P., Bioenergy Unit, Estrada do Paço do Lumiar 22, 1649-038 Lisbon, Portugal; rodrigo.cardeiras@gmail.com (R.C.); ruinabais94@gmail.com (R.N.); francisca.opf@gmail.com (F.F.); belina.ribeiro@lneg.pt (B.R.); luisa.gouveia@lneg.pt (L.G.)

2 GreenCoLab_-Associação Oceano Verde, University of Algarve, Campus de Gambelas, 8005-139 Faro, Portugal; danielfigueiredo@greencolab.com

3 Forest Research Centre, School of Agriculture, University of Lisbon, Tapada da Ajuda, 1349-017 Lisboa, Portugal; cms@isa.ulisboa.pt

4 Chemical Engineering Department, University of Almeria, Ctra. Sacramento, s/n, 04120 Almería, Spain; facien@ual.es

* Correspondence: alice.ferreira@lneg.pt

check for updates

Citation: Ferreira, A.; Figueiredo, D.; Cardeiras, R.; Nabais, R.; Ferreira, F.; Ribeiro, B.; Cordovil, C.M.d.S.; Acién, F.G.; Gouveia, L. Exploring Different Pretreatment Methodologies for Allowing Microalgae Growth in Undiluted Piggery Wastewater. Agronomy 2022, 12, 580. https:// doi.org/10.3390/agronomy12030580

Academic Editor: Sung-Cheol Koh

Received: 19 January 2022

Accepted: 24 February 2022

Published: 26 February 2022

Publisher's Note: MDPI stays neutral with regard to jurisdictional claims in published maps and institutional affiliations.

Copyright: () 2022 by the authors Licensee MDPI, Basel, Switzerland. This article is an open access article distributed under the terms and conditions of the Creative Commons Attribution (CC BY) license (https:// creativecommons.org/licenses/by/ $4.0 /)$.

\begin{abstract}
The overapplication of manure on agricultural soils leads to nitrogen and phosphorus discharge into the aquatic environment, resulting in serious eutrophication problems and decreased water quality. Piggery wastewater (PWW) can be treated by microalgae to recycle nutrients, but the toxic levels of ammonia and organic matter hinder their growth. Fresh water is usually used to dilute PWW, but it is a scarce resource. The implementation of a pretreatment step before microalgae-based treatment could make PWW suitable for microalgae growth. Electrocoagulation, ammonia stripping, photo-Fenton, and constructed wetlands were evaluated as pretreatment methods to reduce ammonia, chemical oxygen demand (COD), color, and total suspended solids. Moreover, the pretreated PWWs were tested to grow the microalga Tetradesmus obliquus. Photo-Fenton showed the best results among the other pretreatments, achieving removal efficiencies above $90 \%$, except for ammonia. This resulted in T. obliquus being capable of growing on undiluted PWW, even at higher ammonia levels, achieving similar biomass productivity to synthetic medium $\left(66.4 \pm 17.8 \mathrm{mg} \cdot \mathrm{L}^{-1} \cdot \mathrm{day}^{-1}\right.$ and $60.1 \pm 10.4 \mathrm{mg} \cdot \mathrm{L}^{-1} \cdot$ day $^{-1}$, respectively) almost doubling with $\mathrm{pH}$ control $\left(116.5 \mathrm{mg} \cdot \mathrm{L}^{-1} \cdot \mathrm{day}^{-1}\right)$. Thus, this pretreatment seems to be the most promising one to incorporate into microalgae-based treatment systems and must be further explored.
\end{abstract}

Keywords: swine wastewater; Tetradesmus obliquus; ammonia stripping; electrocoagulation; photoFenton; constructed wetland

\section{Introduction}

Pork is an important source of protein around the world. According to recent estimates, the European Union is currently one of the largest pig producers, with an average of 148 million pig heads produced in the last 10 years [1]. This industry is estimated to generate 215-430.106 $\mathrm{m}^{3}$ /year (4-8 L/day/pig) of piggery wastewater (PWW) [2], which includes pig excreta combined with the water used to clean the hog housing sheds. Thus, it contains a high organic load, ammonium nitrogen, phosphorus, and recalcitrant organic compounds that hinder the performance of conventional treatment processes. PWW is commonly treated in stabilization ponds, where it is left stored for long periods before land application [3]. However, these generate high emissions of $\mathrm{CO}_{2}$, methane (from anaerobic digestion), ammonia (by volatilization), and hydrogen sulfide (from decomposition), among others [4]. 
While PWW is a problem for piggeries to handle, for microalgae growth, it represents a valuable low-cost and ready to use source of nutrients. The assimilation of the nutrients from PWW in autotrophic microalgal biomass may provide alternative wastewater treatment for pig farming. The produced algal biomass can generate income as a source of animal feed or plant fertilizers and biostimulants for agriculture. Nevertheless, microalga cultivation in PWW still represents a challenge due to the high ammonia levels, high $\mathrm{pH}$, dark color, and significant suspended solid content, resulting in high turbidity $[4,5]$. The increase in $\mathrm{pH}$, due to microalgae photosynthesis and carbon assimilation, shifts the chemical equilibrium from $\mathrm{NH}_{4}{ }^{+}$to $\mathrm{NH}_{3}$, which is more toxic to microalgae cells [5,6]. In addition, the dark color and high turbidity reduce light penetration, lowering the amount of light available for autotrophic growth. The dilution of the PWW can reduce toxic nutrient concentrations to noninhibiting levels while promoting light availability to microalgae cells [7]. However, the use of fresh water, a scarce and precious resource, should be avoided, as it entails economic and ecological issues. This motivates the search for new strategies, such as the integration of a pretreatment process to minimize the toxicity of PWW and assure optimal microalgae growth.

Electrocoagulation (EC) is a popular method in wastewater treatment that has been widely studied for different WW sources owing to its versatility, simple setup, low footprint, and ecofriendly nature [8]. EC acts by destabilizing the charges of the pollutants through electrode-released cations (e.g., $\mathrm{Fe}^{2+}$ or $\mathrm{Al}^{3+}$ ), which form hydroxides or polyhydroxides with a great affinity for dissolved substances or counterions to cause coagulation/adsorption phenomena [9]. Pollutants are aggregated into clusters and separated from the electrolytic mixture by sedimentation, due to the heavier weight of flocs, or by flotation with the help of microbubbles produced by water electrolysis. The key factors for EC are electrode type, electrode distance, current density, $\mathrm{pH}$, the conductivity of the electrolyte, and time. Iron ( $\mathrm{Fe}$ ) and aluminum ( $\mathrm{Al})$ are the most widely used electrode materials because they are readily available and inexpensive, and they have high removal capacity [10]. However, the EC technology is not yet fully optimized to be considered a reliable water treatment technology, since most research is developed using small-scale batch reactors. One of the major challenges is developing a more systematic approach for EC reactor design, operation, and modeling to predict the EC performance and, thus, facilitate the scaling up to meet industrial capacity. Furthermore, research is required to evaluate the performance of EC units operating in continuous flow mode with more effective reactor design [11].

Ammonia stripping (AS) is a well-described method to reduce ammonium nitrogen levels of several wastewaters, due to its easy operation, high efficiency, and process stability $[12,13]$. However, the research on AS applied to PWW for ammonia removal is limited and not always consistent $[13,14]$. AS is based on the principle of mass transfer in which air is injected into the PWW to strip the free ammonia $\left(\mathrm{NH}_{3}-\mathrm{N}\right)$ that is highly volatile. In this process, the wastewater is aerated after adjusting the $\mathrm{pH}$ over 8.5 using alkali [13]. Airflow rate, $\mathrm{pH}$, and temperature are the most influencing parameters on the removal rates of ammonia $[12,13,15]$. Higher temperatures and $\mathrm{pH}$ have been reported to enhance the stripping efficiency, as they promote the formation of $\mathrm{NH}_{3}$ [16]. Typical values found in the literature are $\mathrm{pH} 10-11$, with a temperature up to $80^{\circ} \mathrm{C}$, and airflow rate ranging from 0.5 to $10 \mathrm{vvm}\left(\mathrm{L} \cdot \mathrm{L}^{-1} \cdot \mathrm{min}^{-1}\right)$ [14]. The AS process has several drawbacks, such as fouling problems, which affects stripping performance and entails high operation and maintenance costs, in addition to sludge production and high alkalinity of the effluent, and release of ammonia gas, which can cause additional environmental costs. This latter effect can be minimized by capturing the volatilized ammonia in an adjacent adsorbing unit containing an acid solution (e.g., sulfuric acid to produce ammonium sulfate, which can be used as fertilizer in agriculture) $[12,13]$.

Advanced oxidation processes such as photo-Fenton (PF) have been drawing the attention of researchers for their advantages such as simpler process conditions (e.g., ambient temperature and pressure) and shorter reaction time, while being more economical 
and feasible than conventional methods [17]. In PF, hydrogen peroxide oxidizes Fe, which acts as a catalyst, yielding hydroxyl radicals. The oxidized $\mathrm{Fe}^{3+}$ is quickly reduced to $\mathrm{Fe}^{2+}$ by the action of UV-vis radiation, being regenerated cyclically. Hydroxyl radicals are responsible for the oxidation of organic matter due to their high oxidation potential $\left(E_{o x}^{0}=2.8 \mathrm{~V}\right)$ [18]. They react rapidly in a nonselective manner, which enables the total degradation of organic contaminants, thus generating a smaller volume of solid waste [19]. Moreover, the hydroxyl radicals can oxidize ammonia to nitrate [20], which is less toxic for microalgae growth [6]. The $\mathrm{H}_{2} \mathrm{O}_{2} / \mathrm{Fe}$ ratio is highly important for the efficiency of the method to assure a complete reaction and the full consumption of $\mathrm{H}_{2} \mathrm{O}_{2}$. Furthermore, a prior acidification step is required since the reaction is more effective at acidic $\mathrm{pH}$, which will later require increasing again the $\mathrm{pH}$ to neutral values. These $\mathrm{pH}$ variations all imply added operation costs. The introduction of UV light increases the reaction rate but requires extra costs, which could account for about 35\%. For implementation of these methods, the toxicity of pretreated water must be always assessed since, depending on wastewater origin, the generated compounds might be more toxic than parental compounds. From the economic point of view, reported operation and maintenance values varied from 0.44 to $2.18 \mathrm{EUR} \cdot \mathrm{m}^{-3}$ depending on the lamp used (not including personnel cost) [21]. Nonetheless, these illumination costs can be eliminated when coupling this process to open ponds under solar irradiation [22].

Constructed wetlands (CWs) are a natural, simple, and environmentally friendly technology with low construction and maintenance costs [23], especially suited for small farms in rural communities to allow higher nutrient use efficiency. CWs have several advantages such as the use of solar or wind energies, or gravity. This technique allows the direct use of the PWW, without dilution and the efficient removal of biochemical and chemical oxygen demand and ammoniacal nitrogen. The latter can be converted to nitrates by nitrification due to the passive aeration in these wetlands. The reduced nitrogen levels can be used for microalgae growth, which is a major advantage [24,25]. However, CWs require large areas, and they are vulnerable to climatic changes and temperature; furthermore, the substrates can be easily saturated and plugged, and their performance is highly affected by plant species [26].

The present work aimed to identify the most promising pretreatment methods to treat and enable undiluted PWW for microalgae growth at maximal biomass productivity. For this, the effect of the various operating parameters playing a key role on the pretreatment methodologies ( $\mathrm{pH}$, temperature, time, and reagent concentration) was investigated on the simultaneous degradation of color, COD, TSS, and ammonia nitrogen from PWW. Lastly, the growth of Tetradesmus obliquus was evaluated in the pretreated effluents resulting from optimized conditions.

\section{Materials and Methods}

\subsection{Effluent Feedstock}

The PWW was collected from a stabilization pond in the pig farm Herdade do Pessegueiro-Valorgado, at Glória do Ribatejo, Portugal $\left(39^{\circ} 00^{\prime} 09.0^{\prime \prime} \mathrm{N}, 8^{\circ} 38^{\prime} 45.5^{\prime \prime} \mathrm{W}\right)$ during the month of June and was stored at $4{ }^{\circ} \mathrm{C}$ until handling. The PWW corresponded to the liquid fraction of the pig slurry after solid-liquid separation. Pig slurry comprised pig excreta and water used to clean the housing facilities that accommodate animals at all stages of development, including sows and piglets. Batches of PWW served as substrate for microalga growth after different pretreatment methodologies as described below, at laboratory scale.

\subsection{Electrocoagulation (EC)}

The EC system included an external direct current power source (HY3005D, Mastech: Taipei, Taiwan) connected to a pair of flat electrodes plates $(100 \mathrm{~mm} \times 45 \mathrm{~mm})$ immersed in $500 \mathrm{~mL}$ of PWW contained in $600 \mathrm{~mL}$ glass flasks. The electrodes were fixed at $1 \mathrm{~cm}$ to each other with a submerged surface area of $20 \mathrm{~cm}^{2}$ (Figure 1). All EC tests were performed 
in batch mode, at $150 \mathrm{rpm}$ (IKA Labortechnik ES5, Janke \& Kunkel: Staufen, Germany), and room temperature. The initial $\mathrm{pH}$ was adjusted to 7 using $1 \mathrm{M} \mathrm{HCl}$. The electrodes tested were aluminum, iron, and zinc due to their availability in the laboratory. The current density tested was 4,12 , and $20 \mathrm{~mA} \cdot \mathrm{cm}^{-2}$. After $30 \mathrm{~min}$ of EC, the effluents were left to settle for $30 \mathrm{~min}$. The supernatant was collected, and the $\mathrm{pH}$ was adjusted to 7.0 with $1 \mathrm{M} \mathrm{HCl}$. The pretreated effluent was stored at $4{ }^{\circ} \mathrm{C}$ for further analysis and microalga cultivation experiments, as further described in Section 2.6.

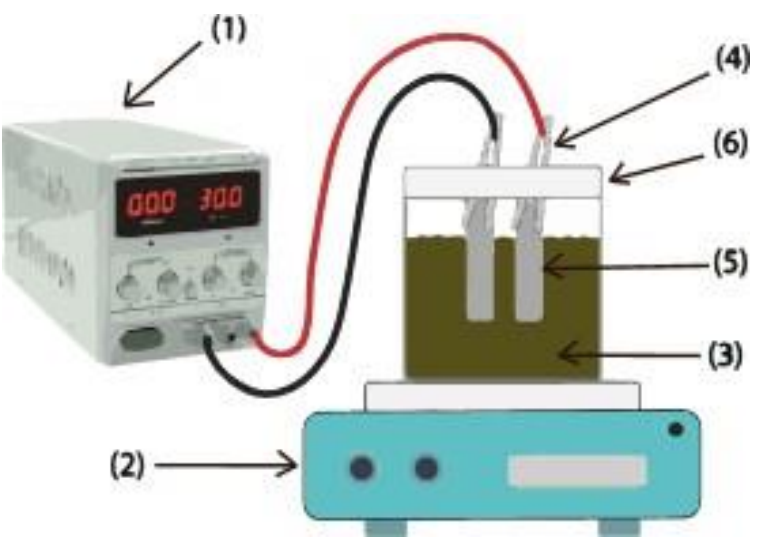

Figure 1. Schematic representation of the experimental set-up for electrocoagulation: 1-direct current power source, 2-magnetic stirrer, 3-piggery wastewater, 4-electrical wires and alligator clips, 5-electrode plates, and 6-stabilizing cap.

\subsection{Ammonia Stripping (AS)}

AS was performed in cylindrical $1 \mathrm{~L}$ bubble column reactors with a working volume of $0.8 \mathrm{~L}$. The effects of $\mathrm{pH}\left(9,10\right.$, and 11) and temperature $\left(25\right.$ and $\left.44{ }^{\circ} \mathrm{C}\right)$ were evaluated on the pollutant removal efficiency, especially ammonia. The temperature was increased by placing reactors in a thermally isolated box with an infrared lamp (Philips $250 \mathrm{~W}$ R40) connected to a temperature controller (Figure 2). The experimental runs were started after $\mathrm{pH}$ adjustments using $6 \mathrm{M} \mathrm{NaOH}$. The reactors were bubbled with air at a fixed airflow of $7.5 \mathrm{vvm}$ for $6 \mathrm{~h}$. In the end, distilled water was added to compensate for the water loss during the process, and the pretreated PWW was left to settle. The supernatant $\mathrm{pH}$ was adjusted to 7.0 using $1 \mathrm{M} \mathrm{HCl}$ and stored for further analysis and microalga cultivation experiments.

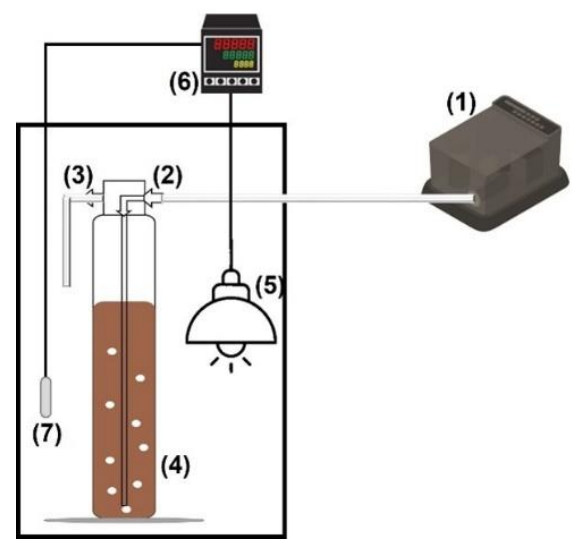

Figure 2. Schematic representation of the experimental setup for the ammonia stripping experiments: 1-air pump, 2-air entrance, 3-air exit, 4-bubble column reactor containing the wastewater, 5-infrared lamp, 6-set point controller, and 7-temperature probe. 


\subsection{Photo-Fenton Process (PF)}

The photo-Fenton experiments were carried out in an installation setup designed and built in the Department of Renewable Energy at LNEG. The set consisted of a wooden box with an interior formed by two sections of a mirror, one containing the light source, which included four Eversun L40/79K lamps (Osram), with unit power of $40 \mathrm{~W}$ (8 W UVA (315-400 nm) and 0.04 W UVB (280-315 nm)), $59 \mathrm{~cm}$ long and $3.8 \mathrm{~cm}$ in diameter, arranged in a circle, and the other where the magnetic stirrer and reactor containing the PWW were located (Figure 3).
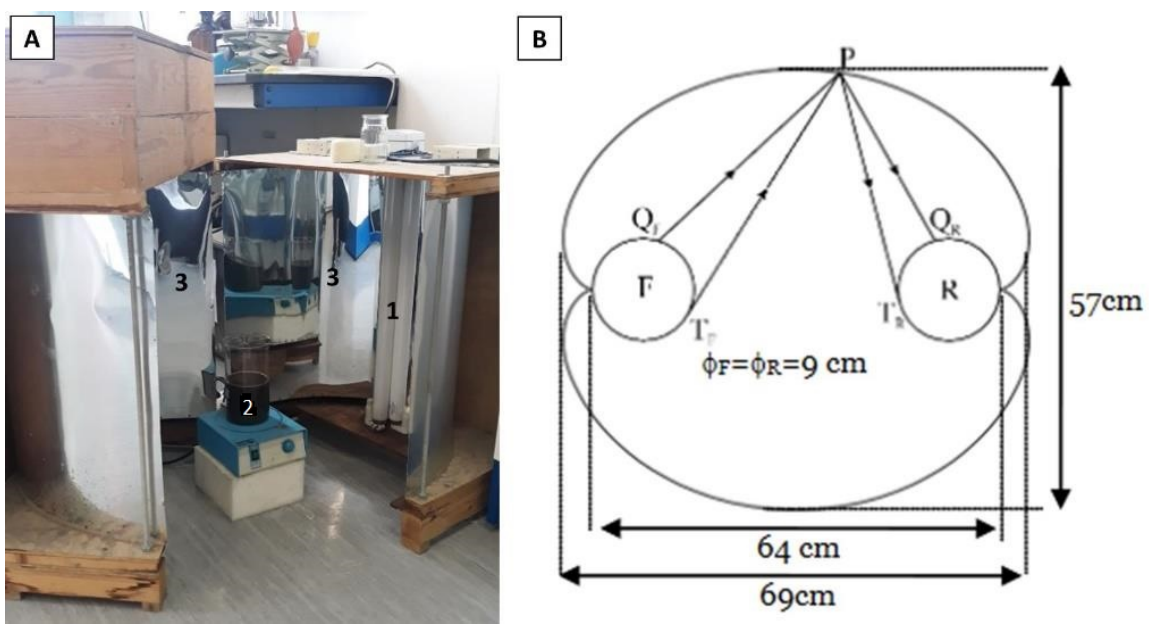

Figure 3. Experimental setup for the photo-Fenton experiments: (A) open montage (1-UV lamps; 2-reaction vessel containing the piggery effluent; 3-mirror section); (B) scheme of the optical device ( $\mathrm{F}$ - energy source; $\mathrm{R}$ - reaction vessel; $\mathrm{P}$-generic point in the mirror section; $\mathrm{TF}, \mathrm{QF}$ - light source points; TR, QR-light receiving points).

The reactions were carried out, in batch mode, in a $1 \mathrm{~L}$ reactor with a working volume of $500 \mathrm{~mL}$. The tested experimental conditions were chosen according to the available literature, as well as preliminary trials. Various concentrations of $\mathrm{Fe}^{2+}$ and $\mathrm{H}_{2} \mathrm{O}_{2}$ were tested: $0.2,0.5$, and $1.0 \mathrm{~g} \mathrm{Fe}^{2+} \cdot \mathrm{L}^{-1}$ and $1,4.9$, and $10.5 \mathrm{~g} \mathrm{H}_{2} \mathrm{O}_{2} \cdot \mathrm{L}^{-1}$. Ferrous sulfate $\left(\mathrm{FeSO}_{4} \cdot 7 \mathrm{H}_{2} \mathrm{O}\right)$ and hydrogen peroxide (35 wt.\%) were used. The initial $\mathrm{pH}$ was first adjusted to 3 using $\mathrm{cc}$. $\mathrm{H}_{2} \mathrm{SO}_{4}$, and then ferrous sulfate was added to the reactor. An acidic $\mathrm{pH}(2-4)$ is crucial to minimize the formation of secondary products less reactive, guaranteeing a high oxidation potential, as well as to avoid the precipitation of iron ions. The reactor was then placed under UV radiation for $120 \mathrm{~min}$ at room temperature and mixed at $400 \mathrm{rpm}$. To avoid the intensive formation of foam, $\mathrm{H}_{2} \mathrm{O}_{2}$ was added in dosages at different times: $1 \mathrm{~g} \cdot \mathrm{L}^{-1}, 4.9 \mathrm{~g} \cdot \mathrm{L}^{-1}$, and $10.5 \mathrm{~g} \cdot \mathrm{L}^{-1}$, at intervals of $30 \mathrm{~min}$. At the end of the process, the residual hydrogen peroxide was determined by iodometric titration with sodium thiosulfate $(0.1 \mathrm{~N})$. The $\mathrm{pH}$ was adjusted to 7.0 using $6 \mathrm{M} \mathrm{NaOH}$, and the effluent was left to settle for $2 \mathrm{~h}$. The supernatant was then filtered through a paper filter $(11 \mu \mathrm{m}$, Whatman) to remove suspended iron precipitates. The pretreated effluent was stored for further analysis and microalga cultivation.

\subsection{Constructed Wetland (CW)}

The PWW was also submitted to a pretreatment using a lab-scale CW. This work was conducted by another team within the project ALGAVALOR consortium, and a full description of the experimental design and the results are detailed in Dias et al. (2020) [27]. They studied the removal of metals and nutrients on CWs microcosms to simulate a vertical subsurface flow CW. Experiments were performed at a laboratory scale using two types of porous substrate (lava rock and expanded clay), and two macrophyte species (Typha latifolia and Phragmites australis). The pretreated effluent resulting from the $\mathrm{CW}$ using $P$. australis 
and expanded clay was compared its potential for microalga cultivation and compared to other pretreatment methods of this work.

\subsection{Microalga Cultivation}

The microalga tested was Tetradesmus obliquus (ACOI 204/07, ACOI Culture Collection, Coimbra University, Portugal) that was previously shown to grow more efficiently on diluted (1/20) piggery effluent [28]. T. obliquus was inoculated in the different undiluted pretreated effluents at an optical density $\left(\mathrm{OD}_{540 \mathrm{~nm}}\right)$ of 0.4 in $50 \mathrm{~mL}$ Erlenmeyer flasks with a working volume of $20 \mathrm{~mL}$. Optimized parameters of EC, AS, PF, and CW for microalgae growth were used to compare each method, while Bristol synthetic medium and untreated PWW were used as controls. The pretreated effluents were further compared to diluted (1:2) PWW. The dilution was prepared with tap water. The cultures were maintained at $150 \mathrm{rpm}$ and room temperature $\left(23-25^{\circ} \mathrm{C}\right)$ under constant fluorescent light $\left(41 \mu \mathrm{E} \cdot \mathrm{m}^{-2} \cdot \mathrm{s}^{-1}\right)$. The cultivation period was 15 days. All experiments were conducted in duplicate.

\subsection{Culture Scale-Up}

The microalga cultures that grew in the pretreated effluents (PWW-PF and PWW-CW) were scaled-up to $1 \mathrm{~L}$ bubble-column PBRs, with a working volume of $800 \mathrm{~mL}$. T. obliquus was inoculated at $0.1 \mathrm{~g} \mathrm{AFDW} \cdot \mathrm{L}^{-1}$, and synthetic medium (Bristol) was used as the control. Microalga cultures were maintained at room temperature $\left(23-25^{\circ} \mathrm{C}\right)$, under continuous fluorescent light $\left(50 \mu \mathrm{E} \cdot \mathrm{m}^{-2} \cdot \mathrm{s}^{-1}\right)$ and with an airflow of $0.6 \mathrm{vvm}$. The cultivation period was 16 days. Growth was monitored by daily measurements of $\mathrm{OD}_{540 \mathrm{~nm}}, \mathrm{pH}$, and quantum yield (Qy) measured with the AquaPen-C AP 110-C (PSI, Drásov, Czech Republic). Qy corresponds to the photosynthetic efficiency of photosystem II in a dark-adapted state $(\mathrm{Fv} / \mathrm{Fm})$. Effects of $\mathrm{pH}$ control and weekly harvesting were then studied in PWW-PF cultures. $\mathrm{pH}$ was increased to 7 every time it fell below 5, according to daily measurements, using $1 \mathrm{M} \mathrm{NaOH}$, while weekly harvesting was performed by centrifuging a certain volume of culture $\left(4000 \times g\right.$ for $5 \mathrm{~min}$ at $\left.4^{\circ} \mathrm{C}\right)$. The volume was determined on the basis of OD measurements at the harvesting time (cultivation cycles of 7 days) to assure a similar initial OD (around 0.2) in all the growing cycles, and the supernatant was returned to the reactor prior to the next growing cycle. In the end, average volumetric productivity $\left(\mathrm{P}_{\mathrm{X}}\right)$ and removal efficiencies (RE) were calculated. All experiments were conducted in duplicate.

\subsection{Wastewater Characterization}

To calculate the RE of the tested pretreatment methodologies, the initial PWW and the pretreated effluents were characterized in terms of ammonia nitrogen, phosphorus, and COD, according to standard methods [29]. The characterization was always performed prior to and immediately after the pretreatment methodologies and microalga cultivation. Ammonium nitrogen was quantified using an ion-selective electrode Crison code: 96 63, using a Crison-Multimeter MM41. A commercial kit was used for the measurement of phosphorus (Phosver 3-Powder Pillows, Cat. 2125-99, HACH) using a HACH DR/2010 spectrophotometer, at $890 \mathrm{~nm}$. COD determination was carried out according to the open reflux method-Method 5220-B [29]. Total suspended solids (TSS) were determined according to the standard methods-Method 2540-D [29]. Color was estimated by measuring the effluent absorbance at $540 \mathrm{~nm}$, which was chosen after an initial absorbance scan over a wavelength range of 200-800 $\mathrm{nm}$.

\section{Results and Discussion}

\subsection{Electrocoagulation (EC)}

According to Table 1, COD removal efficiencies of 35-41\% were found for Zn electrodes, while TSS removal was $20.1 \%$ for $4 \mathrm{~mA} \cdot \mathrm{cm}^{-2}$. Al electrodes showed COD removals of $8-18 \%$, while Fe electrodes obtained values of $6-22 \%$. Contrarily, negative TSS RE values in $\mathrm{Al}$ and Fe electrodes were associated with higher TSS after EC pretreatment, further increasing with higher current density. This could be a result of electrode corrosion, as 
increased current leads to the release of higher $\mathrm{Al}^{3+}$ and $\mathrm{Fe}^{2+}$ contents. The COD removal can be attributed to the formation of hydroxides or polyhydroxides which coagulate and adsorb the pollutants [30]. Higher COD removals (50\%) were found in the literature using Fe electrodes to treat PWW but at higher current densities $\left(30 \mathrm{~mA} \cdot \mathrm{cm}^{-2}\right)$ [31]. The same study [31] reported low ammonia removals (3-10\%) using $\mathrm{Fe}$ and $\mathrm{Al}$ electrodes, which was also obtained in the present work. This could be explained because $\mathrm{NH}_{4}{ }^{+}$ exists in the form of small molecules, which is not easy to flocculate [31]. Some authors reported the need for longer electrolysis time (up to $5 \mathrm{~h}$ ) to increase turbidity and ammonia removal [32], while others reported efficient ammonia removal, but large differences were found among the published results [33]. EC is a very complex system with the dominant oxidation mechanism depending on the chemical composition, $\mathrm{pH}$, anode material, chloride concentration, or operation conditions [34]. Synergic interactions between chemical and physical phenomena could also worsen EC operation, which is especially an issue in more complex wastewater [35].

Table 1. Removal efficiencies (\%) of chemical oxygen demand (COD) and total suspended solids (TSS) obtained after electrocoagulation with different electrode materials and current densities.

\begin{tabular}{cccc}
\hline \multicolumn{2}{c}{ Conditions } & \multicolumn{2}{c}{ Removal Efficiency (\%) } \\
\hline \multirow{2}{*}{ Electrode Material } & $\begin{array}{c}\text { Current Density } \\
\left(\mathbf{m A} \cdot \mathbf{c m}^{-2}\right)\end{array}$ & COD & TSS \\
\hline \multirow{2}{*}{$\mathrm{Al}$} & 4 & $18.4 \pm 2.6$ & $-31.6 \pm 2.2$ \\
& 12 & $7.9 \pm 2.6$ & $-56.9 \pm 0.0$ \\
& 20 & $13.2 \pm 2.6$ & $-56.2 \pm 7.9$ \\
\hline \multirow{2}{*}{$\mathrm{Fe}$} & 4 & $6.0 \pm 3.2$ & $-5.4 \pm 0.0$ \\
& 12 & $9.3 \pm 6.4$ & $-19.2 \pm 4.3$ \\
& 20 & $22.2 \pm 6.5$ & $-33.0 \pm 2.6$ \\
\hline \multirow{2}{*}{$\mathrm{Zn}$} & 4 & $34.7 \pm 3.1$ & $20.1 \pm 2.2$ \\
& 12 & $37.8 \pm 0.0$ & $7.1 \pm 2.2$ \\
& 20 & $40.9 \pm 3.1$ & $9.3 \pm 0.0$ \\
\hline
\end{tabular}

\subsection{Ammonia Stripping ( $A S)$}

The pretreatment by AS was tested to reduce the toxic levels of ammonia in PWW. The effects of $\mathrm{pH}$ and temperature on the removal of ammonia are shown in Figure 4. As expected, the $\mathrm{RE}$ increased with $\mathrm{pH}$, since alkaline environments shift the chemical equilibrium from $\mathrm{NH}_{4}{ }^{+}$to gaseous $\mathrm{NH}_{3}$, which is more volatile [13]. Thus, when the $\mathrm{pH}$ was raised from 9 to 11, ammonia RE increased to $30 \%$. Moreover, temperature also had a positive effect on ammonia $\mathrm{RE}$ due to increased $\mathrm{NH}_{3}$ solubility. However, this was less pronounced at $\mathrm{pH} 11$, as raising the temperature from 25 to $44^{\circ} \mathrm{C}$ only increased $\mathrm{RE}$ by $4 \%(67.8 \pm 1.4 \%$ and $71.7 \pm 2.6 \%$, respectively). This may not be significant enough to justify the cost increment and technical difficulties associated with heating [12]. Thus, the pretreated effluent obtained by AS at $\mathrm{pH} 11$ and $25^{\circ} \mathrm{C}$ (room temperature) was selected to pursue microalga cultivation. However, the ammonium levels in this pretreated effluent were still higher than the general limit of toxicity for microalgae (around $150 \mathrm{mg} \cdot \mathrm{L}^{-1}$ ) [36]. Nonetheless, a dilution of at least 1:2 could be enough to overcome this limitation, which is far better than the previous dilution factors used by Ferreira et al. (2021) [28] and the literature in general (e.g., García et al., 2017 [2]; Godos et al., 2010 [37]; Molinuevo-Salces et al., 2016 [38]). 


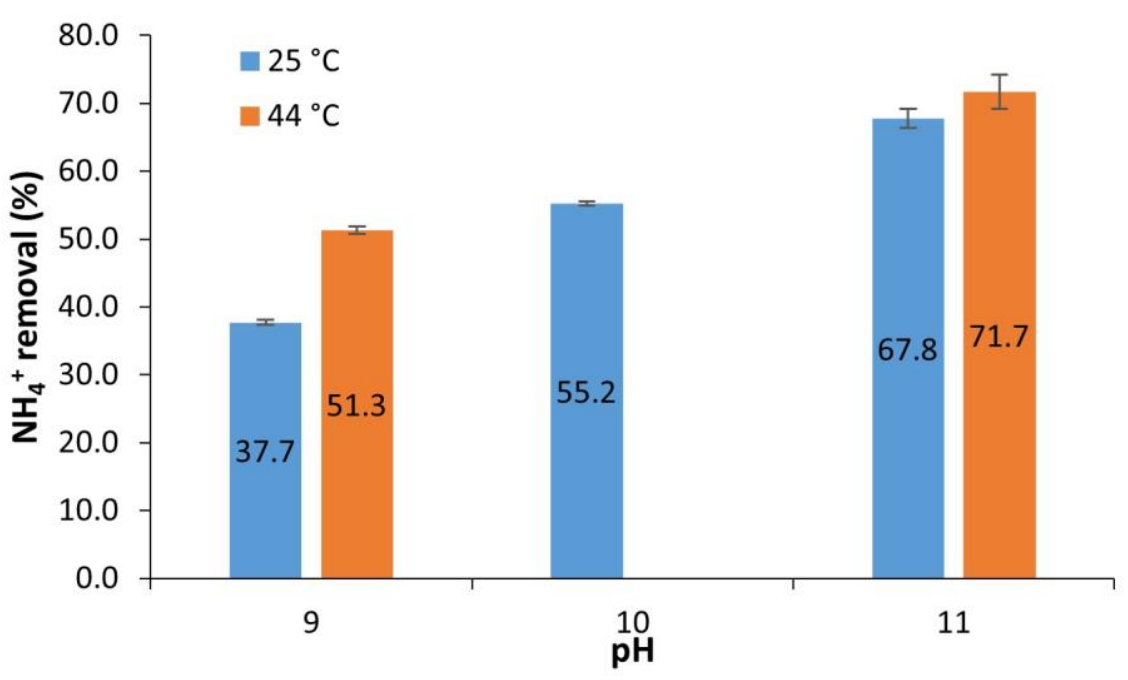

Figure 4. Ammonia removal efficiencies obtained after ammonia stripping with different $\mathrm{pH}$ and temperature. Values are presented as the mean \pm mean deviation $(n=2)$.

\subsection{Photo-Fenton (PF)}

The main objective of photo-Fenton as a pretreatment was to decrease PWW color and organic load so that light could more easily penetrate the microalga culture and allow autotrophic growth, which was achieved. According to Table 3, for all tested conditions, the RE of color and COD was higher than $78 \%$ and $80 \%$, respectively, showing the potential of PF to reduce the organic matter, which consequently decreased the effluent's color, generating clear effluents with a yellowish color. Moreover, the RE of TSS was higher than $85 \%$, achieving near-complete removal $(>98.5 \%)$ for the condition with the highest concentration of iron $\left(1 \mathrm{~g} \mathrm{Fe}^{2+} \cdot \mathrm{L}^{-1}\right)$. These high $\mathrm{RE}$ values are due to the combination of oxidation with iron precipitation when $\mathrm{pH}$ is increased back to 7.0. The formation of denser flocs allows them to be better retained in the filter paper upon filtration, which generates a much clearer effluent. The RE of ammonia, on the other hand, was negligible in all tested conditions (below $10 \%$ ), which could be due to low $\mathrm{H}_{2} \mathrm{O}_{2}$. Indeed, according to some authors, only at very high $\mathrm{H}_{2} \mathrm{O}_{2}$ concentration is it possible to degrade ammonia and generate $\mathrm{N}_{2}$ and nitrate [39,40]. Moreover, organic nitrogen can be decomposed to form products such as molecular nitrogen, nitrate, nitrite, or ammonia, which could result in an increase in the latter in the PF pretreated wastewater [41].

According to residual $\mathrm{H}_{2} \mathrm{O}_{2}$ determinations, only at $1 \mathrm{~g} \mathrm{Fe}^{2+}$. $\mathrm{L}^{-1}$ was it possible to obtain a high decomposition of $\mathrm{H}_{2} \mathrm{O}_{2}$. Iron is an important factor for the PF reaction as it acts as a catalyst to decompose $\mathrm{H}_{2} \mathrm{O}_{2}$ and generate $\mathrm{OH}^{\bullet}$ radicals. Furthermore, nearcomplete removal of $\mathrm{H}_{2} \mathrm{O}_{2}$ is indispensable because values higher than $10 \mathrm{mg} \cdot \mathrm{L}^{-1}$ are toxic to microalgae [42]. In fact, the reaction is highly dependent on the $\mathrm{Fe}^{2+} / \mathrm{H}_{2} \mathrm{O}_{2}$ ratio, which is why this is one of the most important parameters to consider when optimizing the process. Thus, looking at the residual $\mathrm{H}_{2} \mathrm{O}_{2}$ concentration (Table 2), $\mathrm{Fe}^{2+}$ plays a key role in $\mathrm{H}_{2} \mathrm{O}_{2}$ consumption, and only at the highest $\mathrm{Fe}^{2+}$ concentration was there complete consumption of $\mathrm{H}_{2} \mathrm{O}_{2}$ regardless of concentration. For lower Fe ${ }^{2+}$ concentrations, $\mathrm{H}_{2} \mathrm{O}_{2}$ was only half consumed at the dosage of $10.5 \mathrm{~g} \cdot \mathrm{L}^{-1}$. 
Table 2. Removal efficiencies (\%) after photo-Fenton ( $\mathrm{pH} 3$ and $120 \mathrm{~min}$ ) in the tested conditions (Fe $\mathrm{Fe}^{2+}$ and $\mathrm{H}_{2} \mathrm{O}_{2}$ concentrations) for color (given by absorbance measured at $540 \mathrm{~nm}$ ), ammonia $\left(\mathrm{NH}_{4}{ }^{+}\right)$, chemical oxygen demand (COD), and total suspended solids (TSS). The residual $\mathrm{H}_{2} \mathrm{O}_{2}$ present at the end of each run is also shown.

\begin{tabular}{|c|c|c|c|c|c|c|}
\hline \multicolumn{2}{|c|}{ Conditions } & \multicolumn{4}{|c|}{ Removal Efficiency (\%) } & \multirow{2}{*}{$\begin{array}{c}\text { Residual } \\
\mathrm{H}_{2} \mathrm{O}_{2}\left(\mathrm{~g} \cdot \mathrm{L}^{-1}\right)\end{array}$} \\
\hline $\begin{array}{c}\mathrm{Fe}^{2+} \\
\left(\mathrm{g} \cdot \mathrm{L}^{-1}\right)\end{array}$ & $\begin{array}{c}\mathrm{H}_{2} \mathrm{O}_{2} \\
\left(\mathrm{~g} \cdot \mathrm{L}^{-1}\right)\end{array}$ & Color & COD & TSS & $\mathrm{NH}_{4}{ }^{+}$ & \\
\hline \multirow{3}{*}{0.2} & 1.0 & $81.5 \pm 5.0$ & $82.3 \pm 0.8$ & $91.7 \pm 0.5$ & $7.99 \pm 1.76$ & 0.26 \\
\hline & 4.9 & $83.3 \pm 5.3$ & $27.4 \pm 0.0$ & $85.0 \pm 1.3$ & $9.89 \pm 2.57$ & 3.21 \\
\hline & 10.5 & $78.3 \pm 1.2$ & $22.3 \pm 0.0$ & $90.1 \pm 0.8$ & $3.76 \pm 2.57$ & 3.54 \\
\hline \multirow{3}{*}{0.5} & 1.0 & $91.3 \pm 1.6$ & $84.8 \pm 0.0$ & $93.1 \pm 0.1$ & $2.03 \pm 0.58$ & 0.14 \\
\hline & 4.9 & $92.2 \pm 4.4$ & $89.4 \pm 0.4$ & $92.7 \pm 0.3$ & $-1.29 \pm 0.06$ & 1.43 \\
\hline & 10.5 & $88.9 \pm 8.3$ & $84.4 \pm 1.3$ & $93.4 \pm 0.4$ & $-4.13 \pm 1.70$ & 4.17 \\
\hline \multirow{3}{*}{1.0} & 1.0 & $94.5 \pm 1.1$ & $88.7 \pm 0.2$ & $99.9 \pm 0.1$ & $-7.07 \pm 0.52$ & 0.26 \\
\hline & 4.9 & $96.9 \pm 0.7$ & $91.6 \pm 0.5$ & $100 \pm 0$ & $-1.97 \pm 0.29$ & 0.30 \\
\hline & 10.5 & $97.2 \pm 0.5$ & $92.6 \pm 0.5$ & $98.5 \pm 0.1$ & $0.69 \pm 0.30$ & 0.16 \\
\hline
\end{tabular}

3.4. Microalga Growth in the Pretreated Effluents

\subsubsection{Pretreatment Screening}

The growth of the microalga T. obliquus was evaluated on each optimized pretreatment methodology (electrocoagulation, ammonia stripping, photo-Fenton, and constructed wetlands). Table 3 shows the composition of the pretreated effluents used for this experiment:

(i) Electrocoagulation using zinc electrodes and current density of $20 \mathrm{~mA} \cdot \mathrm{cm}^{-2}$.

(ii) Ammonia stripping at room temperature $\left(25^{\circ} \mathrm{C}\right)$ and initial $\mathrm{pH}$ of 11 .

(iii) Photo-Fenton using $1.0 \mathrm{~g} \mathrm{Fe}^{2+} \cdot \mathrm{L}^{-1}$ and $10.5 \mathrm{~g} \mathrm{H}_{2} \mathrm{O}_{2} \cdot \mathrm{L}^{-1}$.

(iv) Constructed wetlands using expanded clay as substrate and P. australis.

Table 3. Composition of the piggery wastewater (PWW) after the different pretreatment methodologies (EC-electrocoagulation; AS-ammonia stripping; PF-photo-Fenton; CW-constructed wetland) compared to raw PWW and diluted 1:20, in terms of chemical oxygen demand (COD), ammonia nitrogen $\left(\mathrm{NH}_{4}{ }^{+}\right)$, phosphate $\left(\mathrm{PO}_{4}{ }^{3-}\right)$, and color given by the absorbance at $540 \mathrm{~nm}$. The $\mathrm{pH}$ was adjusted to 7 in all media before microalga inoculation.

\begin{tabular}{|c|c|c|c|c|c|}
\hline PWW & $\begin{array}{c}\mathrm{COD} \\
\left(\mathrm{mg} \mathrm{O}_{2} \cdot \mathrm{L}^{-1}\right)\end{array}$ & $\begin{array}{c}\mathrm{NH}_{4}^{+} \\
\left(\mathrm{mg} \cdot \mathrm{L}^{-1}\right)\end{array}$ & $\begin{array}{c}\mathrm{PO}_{4}{ }^{3-} \\
\left(\mathrm{mg} \cdot \mathrm{L}^{-1}\right)\end{array}$ & $\begin{array}{c}\text { TSS } \\
\left(\mathrm{mg} \cdot \mathrm{L}^{-1}\right)\end{array}$ & Color \\
\hline Raw & $3759 \pm 71$ & $1500 \pm 7$ & 97.5 & $2575 \pm 45$ & 6.640 \\
\hline $1: 20$ & $184.4 \pm 7.1$ & $64.6 \pm 1.05$ & 6.40 & $90.0 \pm 0.00$ & 0.300 \\
\hline AS & $2766 \pm 71$ & $731.2 \pm 1.1$ & 81.0 & $1285 \pm 125$ & 2.830 \\
\hline $\mathrm{EC}$ & $1489 \pm 71$ & $1329 \pm 12$ & 37.5 & $207.5 \pm 27.5$ & 1.070 \\
\hline $\mathrm{PF}$ & $276.6 \pm 14.2$ & $1209 \pm 11$ & 0.560 & $37.5 \pm 2.5$ & 0.019 \\
\hline $\mathrm{CW}$ & $319.1 \pm 7.1$ & $122.6 \pm 2.5$ & 77.0 & $52.5 \pm 2.5$ & 0.157 \\
\hline
\end{tabular}

Table 3 shows the initial composition of the various wastewaters used for cultivating $T$. obliquus. Except for ammonia, PF was the pretreatment that most decreased the contaminant load from the effluent, being very efficient in removing COD (92.6\%) and color (99.7\%). This method was also highly effective in removing phosphate $(99.4 \%)$, mainly through precipitation with iron. However, this might not be so beneficial for microalgae growth since phosphorus is an essential macronutrient. CW allowed the highest reduction in ammonia $(82 \%)$, but it must be considered that a dilution of $1: 2.5$ was applied to this effluent during the pretreatment process, decreasing the initial ammonia concentration to around $675 \mathrm{mg} / \mathrm{L}$ [27]. AS also allowed reductions in ammonia, TSS, and COD by $51.2 \%$, $50.1 \%$, and $26.4 \%$. Lastly, EC was the least efficient method for all the evaluated parameters.

As can be seen in Figure 5, T. obliquus did not grow in undiluted PWW or AS and EC pretreated effluents. This observation was expected since the RE values on both processes 
were relatively low. In PWW pretreated with CW, there was an initial lag phase of 7 days, but growth started at a good rate, surpassing that in Bristol medium and 1:20 diluted PWW. The effluent pretreated with PF allowed the highest growth rate of all the media, presenting a steady growth throughout the cultivation period. By the 15th day, the microalga growing in CW came very close to the OD values of PF.

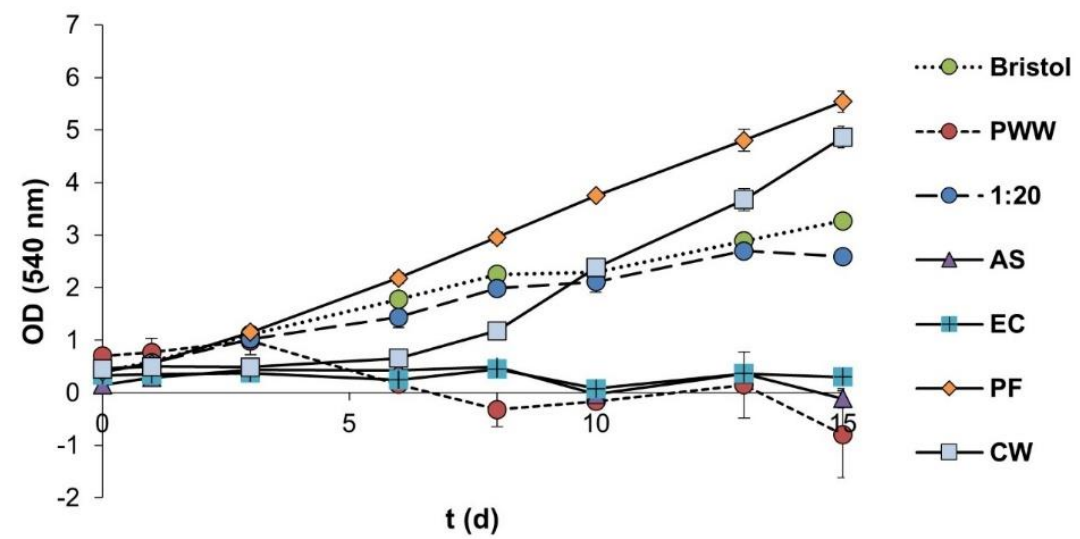

Figure 5. Growth curves for Tetradesmus obliquus cultivated in the pretreated piggery wastewaters: AS-ammonia stripping, EC — electrocoagulation, PF-photo-Fenton, and CW-constructed wetlands. Bristol medium, untreated PWW, and diluted (1:20) effluents were used for comparison. Values are presented as the mean \pm mean deviation $(n=2)$.

\subsubsection{Culture Scale-Up}

Since CW and PF pretreatments allowed the growth of T. obliquus, further growth experiments were performed in $1 \mathrm{~L}$ bubble columns (Figure 6). T. obliquus achieved a final concentration of $1.46 \pm 0.06 \mathrm{~g} \cdot \mathrm{L}^{-1}$ in $\mathrm{PF}$, followed by $1.39 \pm 0.32 \mathrm{~g} \cdot \mathrm{L}^{-1}$ in $\mathrm{CW}$, compared to $0.92 \pm 0.00 \mathrm{~g} \cdot \mathrm{L}^{-1}$ in Bristol medium (Figure 6a). Regarding the $\mathrm{pH}$ (Figure $6 \mathrm{~b}$ ), it increased with the microalga growing in CW, similarly to the Bristol medium. In PF effluent, on the other hand, the $\mathrm{pH}$ decreased to 6 . This can be explained by the proton translocation out of the microalgal cell during ammonium uptake to maintain cell neutrality [43]. This could justify why T. obliquus can grow at high ammonia levels since, in this $\mathrm{pH}$ range, it is mostly in the form of $\mathrm{NH}_{4}{ }^{+}$. Although this was not the optimum $\mathrm{pH}$ range, the microalga achieved higher concentrations in PF effluent compared to the synthetic medium. A sudden drop in Qy suggested that the pretreated effluents first impacted the T. obliquus metabolism, but the cultures recovered by day 7, maintaining similar Qy levels to the culture in synthetic medium from then on (Figure 6c). Lastly, regarding wastewater treatment, T. obliquus could remove $37.3 \pm 1.7 \%$ of $\mathrm{NH}_{4}{ }^{+}$and $48.6 \pm 1.7 \%$ of COD in PF effluent, while it reached complete $\mathrm{NH}_{4}{ }^{+}$removal $(99.8 \pm 0.0 \%)$ and $19.5 \% \pm 0.0 \%$ removal of COD in CW effluent (Figure 6d). However, it should be considered that both effluents differed significantly with respect to the starting levels of ammonia (CW had only about $10 \%$ of the ammonia present in $\mathrm{PF}$ ). Furthermore, one should also consider the $\mathrm{pH}$ increase derived from the microalga growth in $\mathrm{CW}$ effluent, which promoted ammonia volatilization, contributing to its removal. In contrast, for PF, the removal could be completely attributed to the microalga assimilation.

Thus, as the $\mathrm{pH}$ drop did not significantly affect T. obliquus growth in the PF effluent, a more controlled $\mathrm{pH}$ could minimize contamination risks, especially from cyanobacteria that proliferate in alkaline $\mathrm{pH}$ values [44,45]. This could favor the production of monocultures, which is very difficult to achieve when cultivating in wastewater. In addition, PF can promote the removal of pathogens (due to the application of $\mathrm{H}_{2} \mathrm{O}_{2}$ and UV radiation), which could potentially decrease the downstream process costs involving disinfection of the biomass. 

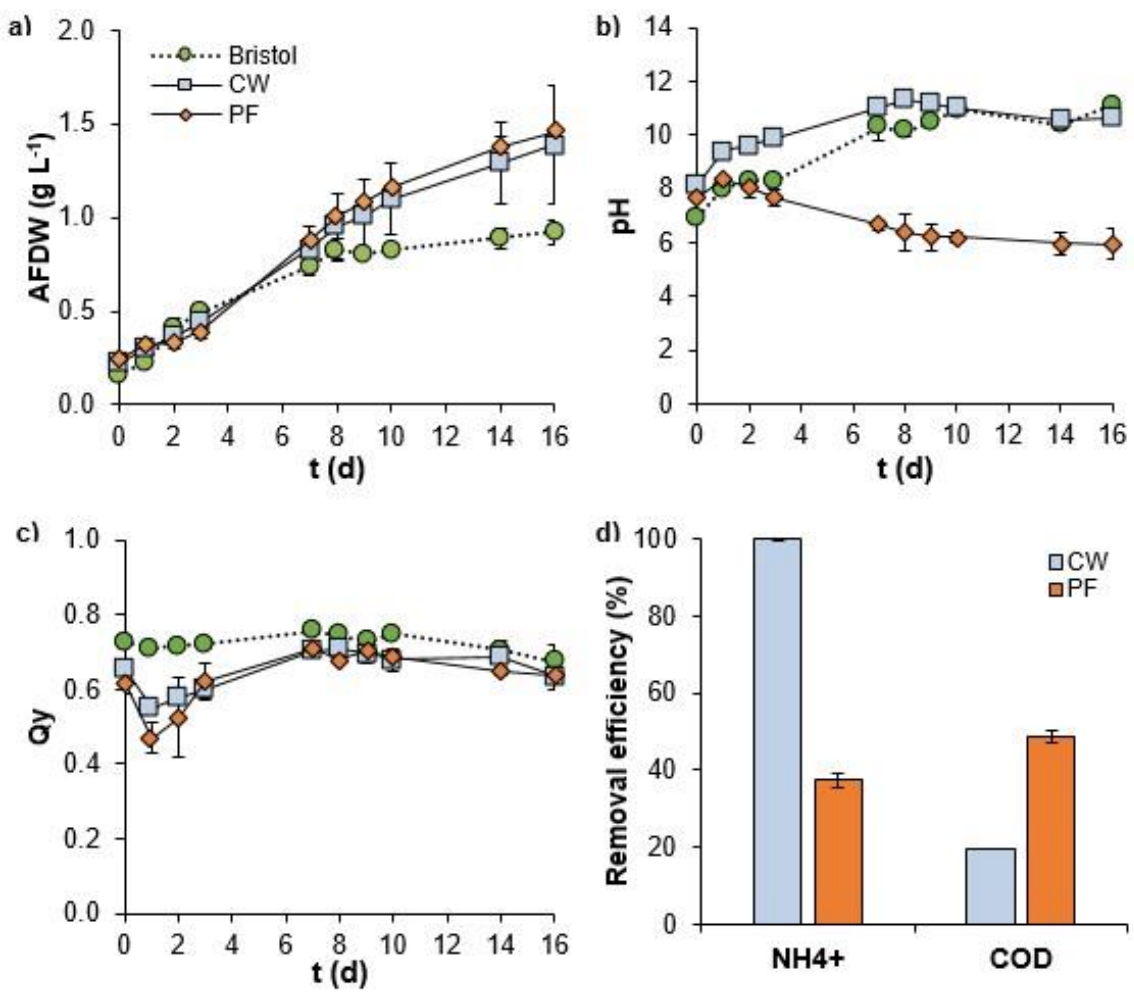

Figure 6. (a) Growth curve in ash-free dry weight (AFDW), (b) $\mathrm{pH},(\mathbf{c})$ quantum yield (Qy), and (d) Removal efficiency of ammonia $\left(\mathrm{NH}_{4}^{+}\right)$and chemical oxygen demand (COD) of Tetradesmus obliquus cultivation in piggery wastewater pretreated by photo-Fenton (PF) and constructed wetland (CW). Bristol medium was used as the control. Values are presented as the mean \pm mean deviation $(n=2)$.

The microalga T. obliquus was shown to efficiently grow in the PF-treated effluent. Yet, the ammonia removal efficiency was rather low after 16 days, and the ammonia levels were still excessive according to Portuguese legislation [46]. Hence, to overcome this, some optimization strategies were applied to enhance microalga growth (Figure 7) and nutrient removal in the PF effluent (Figure 8), including pH control and weekly harvesting to overcome possible cell shadowing at higher concentrations.

Controlling the $\mathrm{pH}$ between 5 and 7 (PF-pH; Figure 7c) seemed to have a positive effect on the microalga growth (Figure 7a) and quantum yield (Figure 7e). After 9 days, the Qy started to decrease in all conditions, but the $\mathrm{pH}$ control $(\mathrm{PF}-\mathrm{pH})$ allowed the culture to maintain a similar Qy to the Bristol culture (Figure 7e). While the T. obliquus grown in $\mathrm{PF}\left(66.4 \pm 17.8 \mathrm{mg} \cdot \mathrm{L}^{-1} \cdot\right.$ day $\left.^{-1}\right)$ achieved similar productivity in Bristol medium $(60.1 \pm$ $10.4 \mathrm{mg} \cdot \mathrm{L}^{-1} \cdot$ day $\left.^{-1}\right)$, with $\mathrm{pH}$ control $(\mathrm{PF}-\mathrm{pH})$, it almost doubled $\left(116.5 \mathrm{mg} \cdot \mathrm{L}^{-1} \cdot \mathrm{day}^{-1}\right)$ (Figure 8a). The improvement verified in the microalga growth can be explained by the fact that the maintenance of a more controlled $\mathrm{pH}$ prevented chloroplast acidification, which can inhibit photosynthesis and microalgal growth [47].

On the other hand, weekly harvesting allowed two cycles of growth of 7 days each (first cycle: 7 days; second cycle: 7-14 days). No growth was verified at the third cycle (14-21 days) (Figure $7 \mathrm{~b}$ ). Without $\mathrm{pH}$ control, the average productivity was $122.1 \pm 3.1$ $\mathrm{mg} \cdot \mathrm{L}^{-1} \cdot$ day $^{-1}$ at the first cycle and $85.1 \pm 7.6 \mathrm{mg} \cdot \mathrm{L}^{-1} \cdot$ day $^{-1}$ at the second cycle (Figure $8 \mathrm{a}$ ). With $\mathrm{pH}$ control, the productivities were similar, $123.2 \pm 8.3$ and $89.0 \pm 6.0 \mathrm{mg} \cdot \mathrm{L}^{-1} \cdot \mathrm{day}^{-1}$ at the first and second cycles, respectively (Figure 8a). The marginal effect of the combination of $\mathrm{pH}$ control with weekly harvesting in the growth of T. obliquus might be related to similar $\mathrm{pH}$ values among both conditions (PF-H and PF-pH $+\mathrm{H}$ ), which meant that it was only necessary to adjust the $\mathrm{pH}$ was at the beginning of each cycle (Figure $7 \mathrm{~d}$ ). Likewise, a high Qy was maintained in the first two cycles and did not differ appreciably among both conditions. By the third cycle, however, it decreased drastically, where no growth was 
observed (Figure 7f). Moreover, the cultures started to change color to yellow, associated with the production of carotenoids, possibly due to nutrient limitation (phosphorus).

As already mentioned, $\mathrm{pH}$ control was highly effective in improving average productivity (Figure 8a). Furthermore, weekly harvesting ( $\mathrm{PF}-\mathrm{H}$ and $\mathrm{PF}-\mathrm{pH}+\mathrm{H}$ ) allowed the microalga to grow at least two times in the same effluent, achieving productivities that, when added to the previous cycle, allowed a bigger production of biomass. This suggests that PF effluent can be recycled at least once for microalga cultivation. Regarding removal efficiencies, $\mathrm{pH}$ control alone did not affect pollutant removal (Figure $8 \mathrm{~b}$ ). The weekly harvesting, however, seemed to have a more significant effect (from $29 \pm 7 \%$ to $43 \pm 3 \%$ for ammonia and from $22 \pm 1 \%$ to $39 \pm 6 \%$ for COD). The removal efficiencies were further improved when both strategies are applied ( $50 \pm 3 \%$ for ammonia, $46 \pm 6 \%$ for COD) (Figure $8 \mathrm{~b}$ ). In addition, light intensities higher than $50 \mu \mathrm{E} \cdot \mathrm{m}^{-2} \cdot \mathrm{s}^{-1}$ could further promote the microalga growth as shown by some studies where improved microalga productivity and biomass composition were observed upon increasing light intensity to 150 and $300 \mu \mathrm{E} \cdot \mathrm{m}^{-2} \cdot \mathrm{s}^{-1}[48]$, as well as under solar radiation [49].
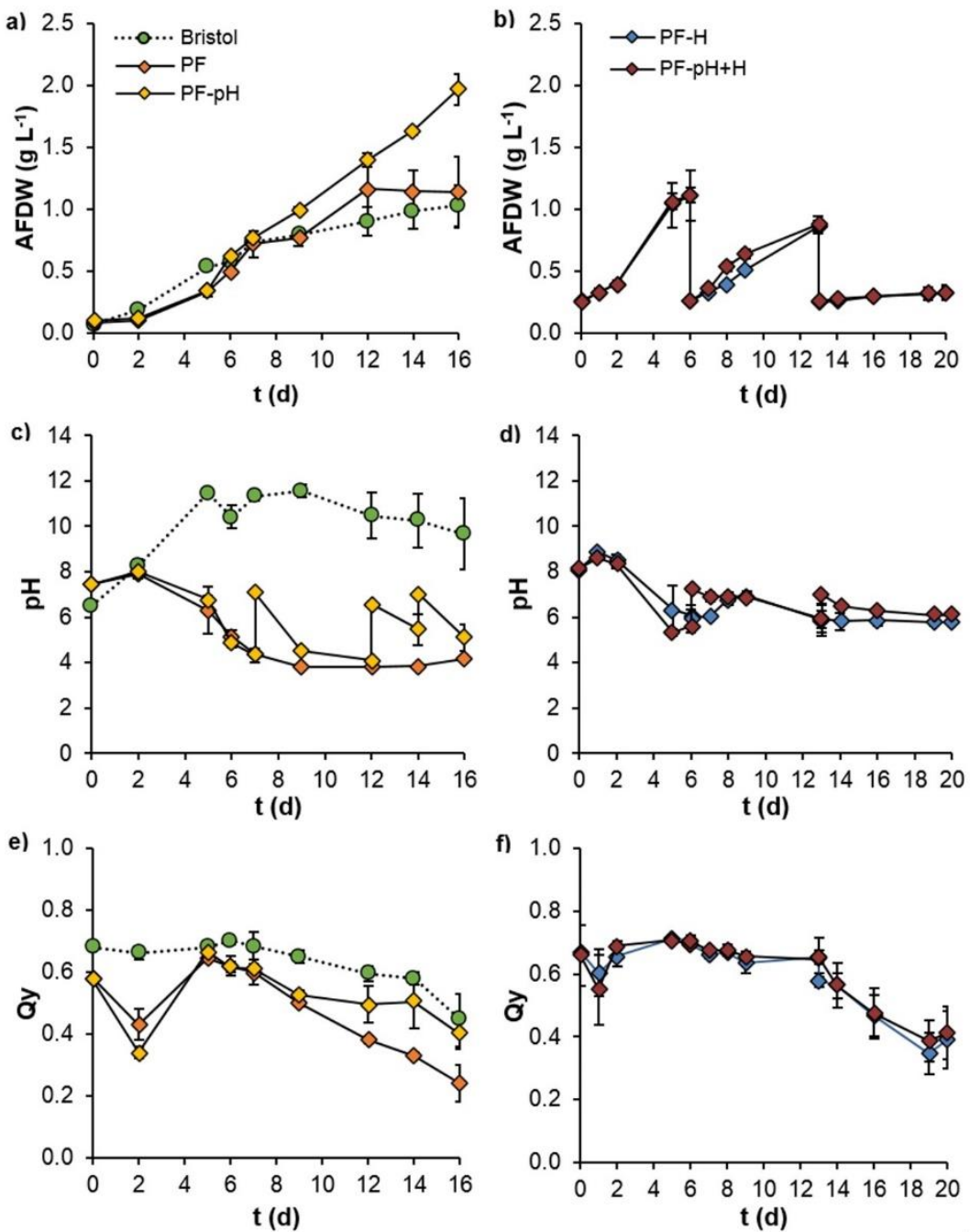

Figure 7. (a,b) Growth curves in ash-free dry weight (AFDW), (c,d) pH, and (e,f) quantum yield (Qy) of Tetradesmus obliquus in piggery wastewater pretreated by Photo-Fenton with combined optimization strategies (PF: no pH control or weekly harvesting; PF-pH: only pH control; PF-H: only weekly harvesting; $\mathrm{PF}-\mathrm{pH}+\mathrm{H}$ : $\mathrm{pH}$ control and weekly harvesting). Bristol medium was used as the control. Values are presented as mean \pm mean deviation $(n=2)$. 
a)

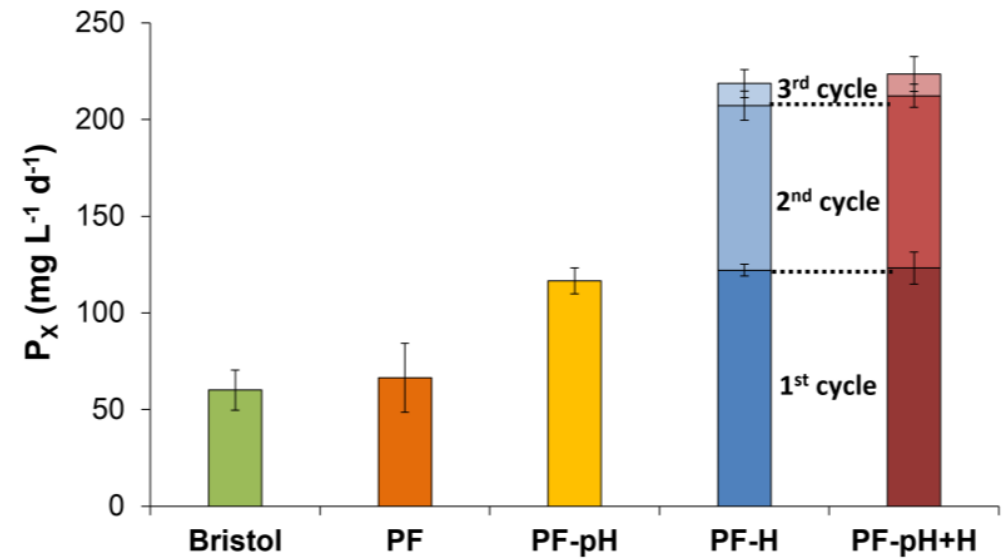

b)

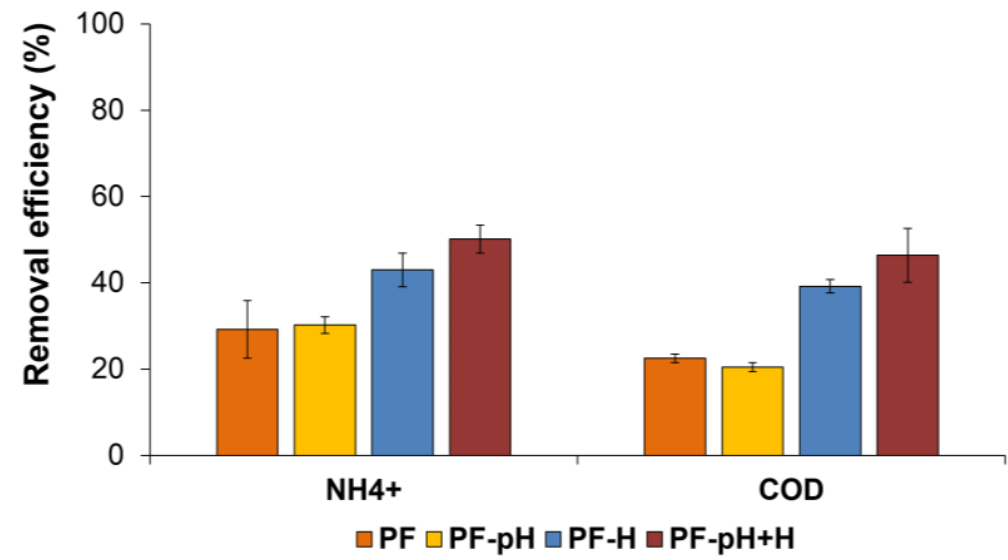

Figure 8. (a) Average biomass productivity and (b) removal efficiencies of ammonia $\left(\mathrm{NH}_{4}^{+}\right)$and chemical oxygen demand (COD) after growth of Tetradesmus obliquus grown in piggery wastewater pre-treated by Photo-Fenton with combined optimization strategies (PF: no pH control or weekly harvesting; $\mathrm{PF}-\mathrm{pH}$ : only $\mathrm{pH}$ control; $\mathrm{PF}-\mathrm{H}$ : only weekly harvesting; $\mathrm{PF}-\mathrm{pH}+\mathrm{H}$ : $\mathrm{pH}$ control and weekly harvesting). Bristol medium was used as the control. Values are presented as the mean \pm mean deviation $(n=2)$.

\section{Conclusions}

Microalgae are promising tools for recovering nutrients from wastewaters, providing clean water and valuable biomass that can be applied in agriculture to reduce water and fertilizer requirements, respectively. However, the high concentration of pollutants in wastewater from specific sources, such as pig farms, can inhibit their growth. Hence, the optimization of these systems by introducing an adjacent chemical process to improve the main treatment with microalgae could be very promising and a sustainable solution to a better management of piggery wastewater with potential nutrient recovery for agricultural use. Photo-Fenton is a rapid process that can partially or completely oxidize organic substances, minimizing their toxicity for the subsequent treatment with microalgae. This work revealed that PF was the best pretreatment for piggery wastewater, as it not only enhanced Tetradesmus obliquus productivity but could also promote biomass safety and quality for sustainable agriculture. The possibility of generating value from the wastes generated in the pig farms that can be injected back into the agricultural production system is a favorable strategy and an important part of the concept of the circular economy.

Author Contributions: Conceptualization, A.F. and L.G.; methodology, A.F., D.F., R.C., R.N., F.F. and B.R.; validation, A.F., D.F. and L.G.; formal analysis, A.F. and L.G.; investigation, A.F., D.F., R.C., R.N., F.F. and B.R.; data curation, A.F., D.F., R.C. and R.N.; writing-original draft preparation, A.F.; writing-review and editing, A.F., D.F., B.R., C.M.d.S.C., F.G.A. and L.G.; supervision, C.M.d.S.C., 
F.G.A. and L.G.; funding acquisition, L.G. All authors have read and agreed to the published version of the manuscript.

Funding: This work was supported by the project ALGAVALOR—Lisboa-01-0247-FEDER-035234, supported by the Operational Program for Competitiveness and Internationalization (COMPETE2020), by the Lisbon Portugal Regional Operational Program (Lisboa 2020), and by the Algarve Regional Operational Program (Algarve 2020) under the Portugal 2020 Partnership Agreement, through the European Regional Development Fund (ERDF); by the Biomass and Bioenergy Research Infrastructure (BBRI)-LISBOA-01-0145-FEDER-022059, supported by the Operational Program for Competitiveness and Internationalization (PORTUGAL2020), by the Lisbon Portugal Regional Operational Program (Lisboa 2020), and by the North Portugal Regional Operational Program (Norte 2020) under the Portugal 2020 Partnership Agreement, through the European Regional Development Fund (ERDF); and by the Red CYTED P319RT0025—RENUWAL—Red Iberoamericana para el Tratamiento de Efluentes con Microalgas. Alice Ferreira is pleased to acknowledge her PhD grant no. SFRH/BD/144122/2019 awarded by Fundação para a Ciência e Tecnologia.

Acknowledgments: The authors would like to thank Valorgado's owners for allowing the access to their facilities to collect the effluent. The authors would also like to thank Graça Gomes and Natércia Sousa (LNEG) for laboratorial assistance and maintenance of the microalgae cultures.

Conflicts of Interest: The authors declare no conflict of interest.

\section{References}

1. Eurostat Number of Pigs 2009-2019. Available online: https:/ / ec.europa.eu/eurostat/databrowser/view/tag00018/default/ table?lang=en (accessed on 2 September 2020).

2. García, D.; Posadas, E.; Grajeda, C.; Blanco, S.; Martínez-Páramo, S.; Acién, G.; García-Encina, P.; Bolado, S.; Muñoz, R. Comparative evaluation of piggery wastewater treatment in algal-bacterial photobioreactors under indoor and outdoor conditions. Bioresour. Technol. 2017, 245, 483-490. [CrossRef] [PubMed]

3. McGahan, E.J.; Phillips, F.A.; Wiedemann, S.G.; Naylor, T.A.; Warren, B.; Murphy, C.M.; Griffith, D.W.T.; Desservettaz, M.; McGahan, E.J.; Phillips, F.A.; et al. Methane, nitrous oxide and ammonia emissions from an Australian piggery with short and long hydraulic retention-time effluent storage. Anim. Prod. Sci. 2016, 56, 1376-1389. [CrossRef]

4. Nagarajan, D.; Kusmayadi, A.; Yen, H.W.; Dong, C.D.; Lee, D.J.; Chang, J.S. Current advances in biological swine wastewater treatment using microalgae-based processes. Bioresour. Technol. 2019, 289, 121718. [CrossRef] [PubMed]

5. Ayre, J.M.; Moheimani, N.R.; Borowitzka, M.A. Growth of microalgae on undiluted anaerobic digestate of piggery effluent with high ammonium concentrations. Algal Res. 2017, 24, 218-226. [CrossRef]

6. Salbitani, G.; Carfagna, S. Ammonium Utilization in Microalgae: A Sustainable Method for Wastewater Treatment. Sustainability 2021, 13, 956. [CrossRef]

7. Azov, Y.; Goldman, J.C. Free Ammonia Inhibition of Algal Photosynthesis in Intensive Cultures. Appl. Environ. Microbiol. 1982, 43, 735-739. [CrossRef] [PubMed]

8. Tahreen, A.; Jami, M.S.; Ali, F. Role of electrocoagulation in wastewater treatment: A developmental review. J. Water Process Eng. 2020, 37, 101440. [CrossRef]

9. Cerqueira, A.; Russo, C.; Marques, M.R.C. Electroflocculation for textile wastewater treatment. Brazilian J. Chem. Eng. 2009, 26, 659-668. [CrossRef]

10. Sahu, O.; Mazumdar, B.; Chaudhari, P.K. Treatment of wastewater by electrocoagulation: A review. Environ. Sci. Pollut. Res. 2014, 21, 2397-2413. [CrossRef] [PubMed]

11. Moussa, D.T.; El-Naas, M.H.; Nasser, M.; Al-Marri, M.J. A comprehensive review of electrocoagulation for water treatment: Potentials and challenges. J. Environ. Manag. 2017, 186, 24-41. [CrossRef]

12. Kinidi, L.; Tan, I.A.W.; Abdul Wahab, N.B.; Tamrin, K.F.B.; Hipolito, C.N.; Salleh, S.F. Recent Development in Ammonia Stripping Process for Industrial Wastewater Treatment. Int. J. Chem. Eng. 2018, 2018, 3181087. [CrossRef]

13. Folino, A.; Calabrò, P.S.; Zema, D.A. Effects of Ammonia Stripping and Other Physico-Chemical Pretreatments on Anaerobic Digestion of Swine Wastewater. Energies 2020, 13, 3413. [CrossRef]

14. Folino, A.; Zema, D.A.; Calabrò, P.S. Environmental and Economic Sustainability of Swine Wastewater Treatments Using Ammonia Stripping and Anaerobic Digestion: A Short Review. Sustainability 2020, 12, 4971. [CrossRef]

15. Kim, E.J.; Kim, H.; Lee, E. Influence of Ammonia Stripping Parameters on the Efficiency and Mass Transfer Rate of Ammonia Removal. Appl. Sci. 2021, 11, 441. [CrossRef]

16. Zhang, L.; Lee, Y.W.; Jahng, D. Ammonia stripping for enhanced biomethanization of piggery wastewater. J. Hazard. Mater. 2012, 199-200, 36-42. [CrossRef]

17. Jain, B.; Singh, A.K.; Kim, H.; Lichtfouse, E.; Jain, B.; Singh, A.K.; Kim, H.; Lichtfouse, E.; Treatment, V.S. Treatment of organic pollutants by homogeneous and heterogeneous Fenton reaction processes. Environ. Chem. Lett. 2019, 16, 947-967. [CrossRef] 
18. Sánchez Pérez, J.A.; Román Sánchez, I.M.; Carra, I.; Cabrera Reina, A.; Casas López, J.L.; Malato, S. Economic evaluation of a combined photo-Fenton/MBR process using pesticides as model pollutant. Factors affecting costs. J. Hazard. Mater. 2013, 244-245, 195-203. [CrossRef]

19. Babuponnusami, A.; Muthukumar, K. A review on Fenton and improvements to the Fenton process for wastewater treatment. J. Environ. Chem. Eng. 2014, 2, 557-572. [CrossRef]

20. Pani, N.; Tejani, V.; Anantha-Singh, T.S.; Kandya, A. Simultaneous removal of COD and Ammoniacal Nitrogen from dye intermediate manufacturing Industrial Wastewater using Fenton oxidation method. Appl. Water Sci. 2020, 10, 1-7. [CrossRef]

21. Rueda-Márquez, J.J.; Levchuck, I.; Manzano, M.; Sillanpää, M. Toxicity Reduction of Industrial and Municipal Wastewater by Advanced Oxidation Processes (Photo-Fenton, UVC/H2O2, Electro-Fenton and Galvanic Fenton): A review. Catalysts 2020, 10, 612. [CrossRef]

22. Soriano-Molina, P.; Plaza-Bolaños, P.; Lorenzo, A.; Agüera, A.; García Saánchez, J.L.; Malato, S.; Sánchez Pérez, J.A. Assessment of solar raceway pond reactors for removal of contaminants of emerging concern by photo-Fenton at circumneutral $\mathrm{pH}$ from very different municipal wastewater effluents. Chem. Eng. J. 2019, 366, 141-149. [CrossRef]

23. Abbasi, H.N.; Xie, J.; Hussain, S.I.; Lu, X. Nutrient removal in hybrid constructed wetlands: Spatial-seasonal variation and the effect of vegetation. Water Sci. Technol. 2019, 79, 1985-1994. [CrossRef] [PubMed]

24. Srivastava, P.; Yadav, A.K.; Garaniya, V.; Abbassi, R. Constructed wetland coupled microbial fuel cell technology: Development and potential applications. In Biomass, Biofuels, Biochemicals: Microbial Electrochemical Technology: Sustainable Platform for Fuels, Chemicals and Remediation; Elsevier: Amsterdam, The Netherlands, 2018; pp. 1021-1036. ISBN 9780444640529.

25. Harrington, C.; Scholz, M. Assessment of pre-digested piggery wastewater treatment operations with surface flow integrated constructed wetland systems. Bioresour. Technol. 2010, 101, 6950-6960. [CrossRef] [PubMed]

26. Nuamah, L.A.; Li, Y.; Pu, Y.; Nwankwegu, A.S.; Haikuo, Z.; Norgbey, E.; Banahene, P.; Bofah-Buoh, R. Constructed wetlands, status, progress, and challenges. The need for critical operational reassessment for a cleaner productive ecosystem. J. Clean. Prod. 2020, 269, 122340. [CrossRef]

27. Dias, S.; Mucha, A.P.; Duarte Crespo, R.; Rodrigues, P.; Almeida, C.M.R. Livestock Wastewater Treatment in Constructed Wetlands for Agriculture Reuse. Int. J. Environ. Res. Public Health 2020, 17, 8592. [CrossRef] [PubMed]

28. Ferreira, A.; Melkonyan, L.; Carapinha, S.; Ribeiro, B.; Figueiredo, D.; Avetisova, G.; Gouveia, L. Biostimulant and biopesticide potential of microalgae growing in piggery wastewater. Environ. Adv. 2021, 4, 100062. [CrossRef]

29. APHA Standard Methods for the Examination of Water and Wastewater, 20th ed.; American Public Health Association: Washington, DC, USA, 1998; Volume 51, ISBN 0002-9572.

30. Ghernaout, D.; Ghernaout, B.; Kellil, A. Natural organic matter removal and enhanced coagulation as a link between coagulation and electrocoagulation. New Pub Balaban 2012, 2, 203-222. [CrossRef]

31. Chen, R.F.; Wu, L.; Zhong, H.T.; Liu, C.X.; Qiao, W.; Wei, C.H. Evaluation of electrocoagulation process for high-strength swine wastewater pretreatment. Sep. Purif. Technol. 2021, 272, 118900. [CrossRef]

32. Lei, X.; Maekawa, T. Electrochemical treatment of anaerobic digestion effluent using a Ti/Pt-IrO 2 electrode. Bioresour. Technol. 2007, 98, 3521-3525. [CrossRef]

33. Lourinho, G.; Brito, P.S.D. Electrolytic Treatment of Swine Wastewater: Recent Progress and Challenges. Waste Biomass Valorization 2020, 12, 553-576. [CrossRef]

34. Yavuz, Y.; Ögütveren, Ü.B. Treatment of industrial estate wastewater by the application of electrocoagulation process using iron electrodes. J. Environ. Manag. 2018, 207, 151-158. [CrossRef]

35. Holt, P.; Barton, G.; Mitchell, C. Electrocoagulation as a wastewater treatment. Third Annu. Aust. Environ. Eng. Res. Event 1999, 1000, 41-46.

36. Collos, Y.; Harrison, P.J. Acclimation and toxicity of high ammonium concentrations to unicellular algae. Mar. Pollut. Bull. 2014, 80, 8-23. [CrossRef] [PubMed]

37. Godos, I.d.; Vargas, V.A.; Blanco, S.; González, M.C.G.; Soto, R.; García-Encina, P.A.; Becares, E.; Muñoz, R. A comparative evaluation of microalgae for the degradation of piggery wastewater under photosynthetic oxygenation. Bioresour. Technol. 2010, 101, 5150-5158. [CrossRef] [PubMed]

38. Molinuevo-Salces, B.; Mahdy, A.; Ballesteros, M.; González-Fernández, C. From piggery wastewater nutrients to biogas: Microalgae biomass revalorization through anaerobic digestion. Renew. Energy 2016, 96, 1103-1110. [CrossRef]

39. Goi, A.; Trapido, M. Hydrogen peroxide photolysis, Fenton reagent and photo-Fenton for the degradation of nitrophenols: A comparative study. Chemosphere 2002, 46, 913-922. [CrossRef]

40. Zoh, K.D.; Stenstrom, M.K. Fenton oxidation of hexahydro-1,3,5-trinitro-1,3,5-triazine (RDX) and octahydro-1,3,5,7-tetranitro1,3,5,7-tetrazocine (HMX). Water Res. 2002, 36, 1331-1341. [CrossRef]

41. Velásquez, M.; Santander, I.P.; Contreras, D.R.; Yáñez, J.; Zaror, C.; Salazar, R.A.; Pérez-Moya, M.; Mansilla, H.D. Oxidative degradation of sulfathiazole by Fenton and photo-Fenton reactions. J. Environ. Sci. Health-Part A Toxic/Hazardous Subst. Environ. Eng. 2014, 49, 661-670. [CrossRef]

42. Pulgarin, A.; Giannakis, S.; Pulgarin, C.; Ludwig, C.; Refardt, D. A novel proposition for a citrate-modified photo-Fenton process against bacterial contamination of microalgae cultures. Appl. Catal. B Environ. 2020, 265, 118615. [CrossRef]

43. Eustance, E.; Gardner, R.D.; Moll, K.M.; Menicucci, J.; Gerlach, R.; Peyton, B.M. Growth, nitrogen utilization and biodiesel potential for two chlorophytes grown on ammonium, nitrate or urea. J. Appl. Phycol. 2013, 25, 1663-1677. [CrossRef] 
44. Mutoti, M.; Gumbo, J.; Jideani, A.I.O. Occurrence of cyanobacteria in water used for food production: A review. Phys Chem Earth 2022, 125, 103101. [CrossRef]

45. Ji, X.; Verspagen, J.M.H.; Stom, M.; Huisman, J. Competition between cyanobacteria and green algae at low versus elevated $\mathrm{CO}_{2}$ : Who will win, and why? J. Exp. Bot. 2017, 68, 3815-3828. [CrossRef] [PubMed]

46. Decree-Law No 236/98 Decree-Law 236/98 of the Portuguese Ministry of the Environment of 1 August establishing water quality standards. Diário da República I Série-A 1998, 3676-3722.

47. Solovchenko, A.; Khozin-Goldberg, I. High- $\mathrm{CO}_{2}$ tolerance in microalgae: Possible mechanisms and implications for biotechnology and bioremediation. Biotechnol. Lett. 2013, 35, 1745-1752. [CrossRef]

48. Nzayisenga, J.C.; Farge, X.; Groll, S.L.; Sellstedt, A. Effects of light intensity on growth and lipid production in microalgae grown in wastewater. Biotechnol. Biofuels 2020, 13, 1-8. [CrossRef]

49. Metsoviti, M.N.; Papapolymerou, G.; Karapanagiotidis, I.T.; Katsoulas, N. Effect of Light Intensity and Quality on Growth Rate and Composition of Chlorella vulgaris. Plants 2020, 9, 31. [CrossRef] 